（昭和 37 年 8 月 16 日受理）

生糸のパパイン酵素精練によるラウジネス繊維抑制効果について

\author{
神戸生釆検查所* 村上茂・平田行 \\ 日本ブラッドパンク社** 古田幸一
}

\title{
THE CONTROLLING EFFECTS ON LOUSINESS FIBERS WHEN RAW SILK DEGUMMED WITH PAPAIN ENZYME.
}

\author{
By Shigeru Murakami*, Akira Hirata* and Köichi Furuta*** \\ *(Kobe Silk Conditioning House, Kobe City, Japan) \\ **(Japan Blood Bank Co., Ltd., Osaka City, Japan)
}

\begin{abstract}
Soap solution is generally used as degumming agent on raw silk, but the papain enzyme also can be used. We have studied under various conditions the controlling effects of the solution on the degree of appearance of lousiness fibers and obtained the following results :

I) In the case of papain enzyme solution treatment, classification results of exfoliation test shows $7 \sim 10 \%$ higher.

2) Sodium bisulphite, hydrosulphite and sodium sulphite are effective agent as an activator, especially hydrosulphite brings forth better results than the others.
\end{abstract}

(Received August 16, 1962)

\section{1. 楮言}

生系の精練によつて発生するフィプロインの分枝絾維 (以下ラウジネス織維し称す) め抑制法については種々 研筑が進められている方，理想的のものは未だ発表され ていない。

パパイン酵势による精練方法については，十でに報

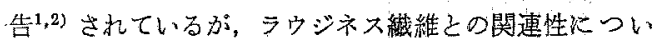

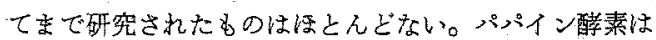
タンパク分解醅素であり，比輘的低温で処理できるの でこれによる精練がラウジネス緎維の発生をいかに㧕 制する效果が台るか，付活剂の種類をがて，石けん精 練の場合と比較検討したので，その結果を報告する。

\section{2. 実験 方 法}

\section{（1）供試生系むよび酵素}

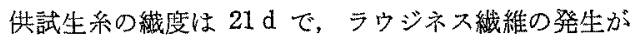

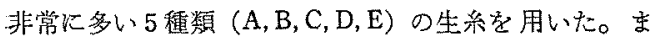
※パパイン酵素は日本ブラッドバンク社製非食用 C-400 荙用いた。

\section{（2）精練染色方法}

先ず供試生系を $72 \mathrm{~cm} \times 23 \mathrm{~cm}$ の中空金属枠飞 5 区 (パネル）に分けて巻取り，後述のように各敖の処理条
件で精練後水洗し，ただちに $60^{\circ} \mathrm{C}$ に加温した $0.04 \%$ メ チレンプルー水溶液中に 20 分間浸せして染色し. 後 水洗風乾する。比较のために常法による $0.5 \%$ 石け ん溶液中江 $99.6^{\circ} \mathrm{C}$ 前後て 1 時間精練了場合（以下河 けん法之称す）歹行なつた。

\section{(3) 加温方法}

精練槽の加温法としては精練槽龙直接ガスパーナーで 加温する方法（以下直接加温法と称す）上間接儿二重槽 によつて加温するち法 (以下間接加温法と称す) を行な Dto

\section{（4）付活㶡の種類}

付活剂としては酸性再硫酸ソーダ $\left(\mathrm{NaHSO}_{3}\right)$ ，ハイド ロナルフォイト，チォ硫酸りーダ $\left(\mathrm{Na}_{2} \mathrm{~S}_{2} \mathrm{O}_{3}\right)$ 呿よび亚 硫酸ソーダ $\left(\mathrm{Na}_{2} \mathrm{SO}_{3}\right)$ などを用いて比較した。

\section{（5）評価の方法}

精練, 染色, 水洗, 夙乾後の亲条パネルを展開して一

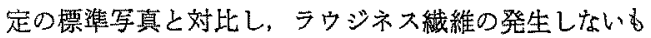
のを100点として採点した。なお 1 回の精練儿は 20 ハ ネルー゙つ行ない，その各パホルを採点し，平均したすの (以下平均点之称す)，最も悪いもの5 ペネルの平均点 (以下劣等点と称す) と，これらの平均点と劣等点の平 均したもの（以下等級点と称す）の3種類で結果な表示 した。 


\section{3. 実 験 結 果}

（1）付活凪に $\mathrm{NaHSO}_{3}$ を用い，直接加温法によつ た場合

供試生糸として A, B , C , D の 4 種類を用い，パパイン 酵素 $0.1 \%(70 \mathrm{~g}), \mathrm{NaHSO}_{3} 0.25 \%(175 \mathrm{~g})$ の割合に

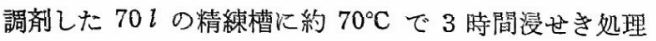
して後, 前記の方法で染色し, そのラウジネス発生状態 を採点調査した結果は次の第 1 表および第 1 図 (A) (B) のようである。なおこのパパインによる精練条件は既 報2)ように間接加温法に上る生系精練の場合の適正処 理条件である。また $0.5 \%$ 石けん水溶液で同一時間, 大 体同一温度で精練, 染色した場合と, 前述の石けん法も 行ない,これらの 3 方法による結果を比較してみた。

すなわち第1表および第1図(A)で明らかなように, パパイン処理による生系は石け九処理（第1図(B)）の 場合に比較して著しく良好な成績を示し，ほとんど完全 にラウジネス故維を抑制している。

ただこのパパイン処理生系を影改鏡で観察すると第 2 図(A)のように, セリシンの残存が多少認められるが, 石けん精練の場合は第 2 図(B)の上5にほとんど認めら れない。これは直接加温法によつたために醅素の活性度 が低下したためと考劣られる。

\begin{tabular}{|c|c|c|c|c|c|c|}
\hline $\begin{array}{l}\text { 供試 } \\
\text { 生棌 }\end{array}$ & $\begin{array}{l}\text { 実験 } \\
\text { 番号 }\end{array}$ & $\begin{array}{l}\text { 表要 精 } \\
\text { 練 剂 }\end{array}$ & $\begin{array}{l}\text { 平均精 } \\
\text { 練温度 }\end{array}$ & 平均点 & 劣等点 & 等被点 \\
\hline \multirow{3}{*}{ A } & 1 & | パパイン & $\begin{array}{l}{ }^{\circ} \mathrm{C} \\
70^{2}\end{array}$ & 97.00 & 95.00 & 96.00 \\
\hline & 2 & 石け儿 & " & 80.50 & 72.00 & 76.25 \\
\hline & 3 & " & 99.6 & 66.25 & 60.00 & 63.12 \\
\hline \multirow{3}{*}{ B } & 4 & パパイン & 70 & 91.25 & 86.00 & 88.62 \\
\hline & 5 & 石けん & "I & 70.75 & 63.00 & 66.87 \\
\hline & 6 & " & 99.6 & 76.75 & 69.00 & 72.87 \\
\hline \multirow{3}{*}{$\mathrm{C}$} & 7 & パパイン & 70 & 94.25 & 89.00 & 91.62 \\
\hline & 8 & 石けん & $" 1$ & 93.25 & 86.00 & 89.62 \\
\hline & 9 & " & 99.6 & 65.50 & 60.00 & 62.75 \\
\hline \multirow{3}{*}{ D } & 10 & パパイン & 70 & 93.50 & 90.00 & 91.75 \\
\hline & 11 & 石けん & $" 1$ & 75.75 & 64.00 & 69.87 \\
\hline & 12 & $"$ & 99.6 & 68.00 & 59.00 & 63.50 \\
\hline
\end{tabular}

（2）付活鼡に $\mathrm{NaHSO}_{3}$ を用い，間接加温法によつ た場合

供試生系として C, D E E の 3 種を用い“前記の (1) と 同じ実験を間接加温法により行なつた結果は次の第 2 表 および第 3 図，第 4 図のよらである。ただし本実験にお いては $5 \mathrm{~g}$ 内外の生系を精秤して, 精練槽に同時に投入 してその練減歩合も求めて見た。

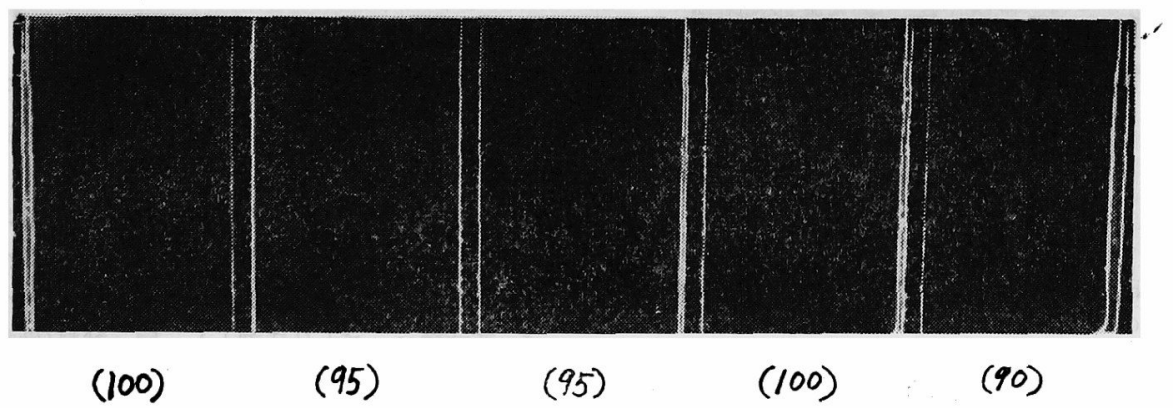

Fig. 1 (A). Representative photograph in test No. 4.

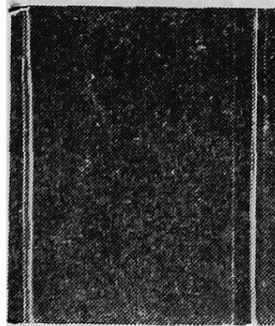

(75)

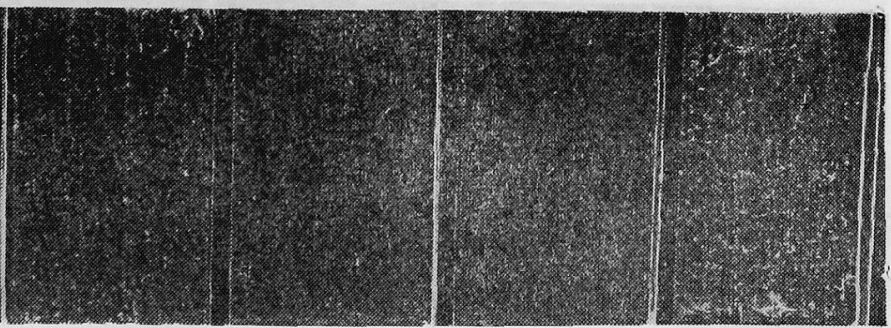

(70)
(80)
(65)

Fig. 1 (B). Representative photograph in test No. 5. 


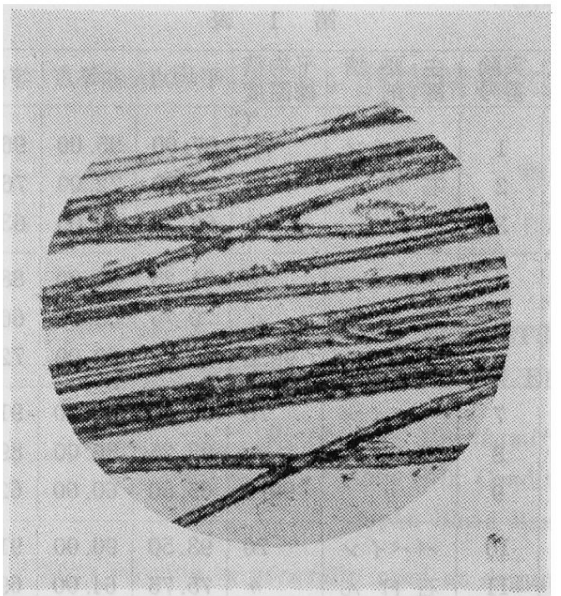

Fig. 2 (A). Degummed silk treated with papain solution.

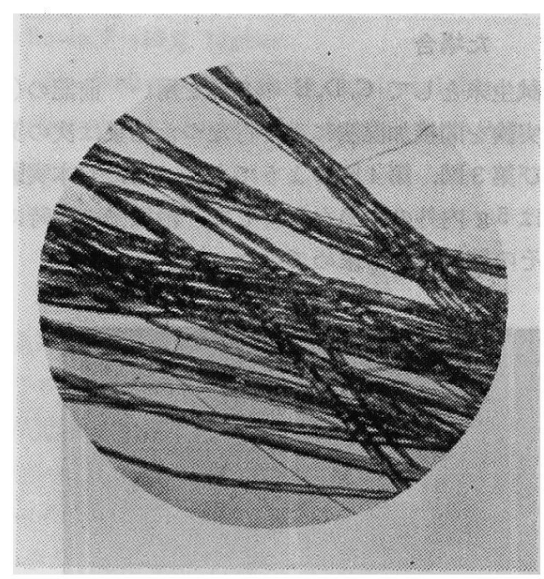

Fig. 2(B). Degummed silk treated with soap solution.

本穾験においてもパパイン酥素精練による場合は相当 ラウジネス緘維の発生を抑制することができるが第 2 表

\begin{tabular}{|c|c|c|c|c|c|c|c|}
\hline \multicolumn{2}{|c|}{ 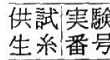 } & $\begin{array}{l}\text { 主要 精 } \\
\text { 練剂 }\end{array}$ & \begin{tabular}{|}
$\mid \bar{F}$ 均精| \\
縲温度
\end{tabular} & & & 等級点 & 練減密 \\
\hline C & $\begin{array}{l}13 \\
14\end{array}$ & $\begin{array}{l}\text { パイン } \\
\text { 石けん }\end{array}$ & $\begin{array}{c}{ }^{\circ} \mathrm{C} \\
70 \\
99.6\end{array}$ & $\begin{array}{l}90.25 \\
67.25\end{array}$ & $\begin{array}{l}85.00 \\
62.00\end{array}$ & $\begin{array}{l}87.62 \\
64.62\end{array}$ & $\begin{array}{l}\% \% \\
18.12 \\
22.08\end{array}$ \\
\hline$D$ & $\begin{array}{l}15 \\
16\end{array}$ & $\begin{array}{l}\text { パパイ } \\
\text { 石けん }\end{array}$ & $\begin{array}{c}70 \\
99.6\end{array}$ & $\begin{array}{l}90.75 \\
69.00\end{array}$ & $\begin{array}{l}85.00 \\
61.00\end{array}$ & $\begin{array}{l}87.87 \\
65.00\end{array}$ & $\begin{array}{l}18.70 \\
22.32\end{array}$ \\
\hline$E$ & $\begin{array}{l}17 \\
18\end{array}$ & $\begin{array}{l}\text { ペパイン } \\
\text { 石けん }\end{array}$ & $\begin{array}{c}70 \\
99.6\end{array}$ & $\begin{array}{l}95.75 \\
71.75\end{array}$ & $\begin{array}{l}94.00 \\
64.00\end{array}$ & $\begin{array}{l}94.87 \\
67.87\end{array}$ & $\begin{array}{l}18.13 \\
20.22\end{array}$ \\
\hline
\end{tabular}

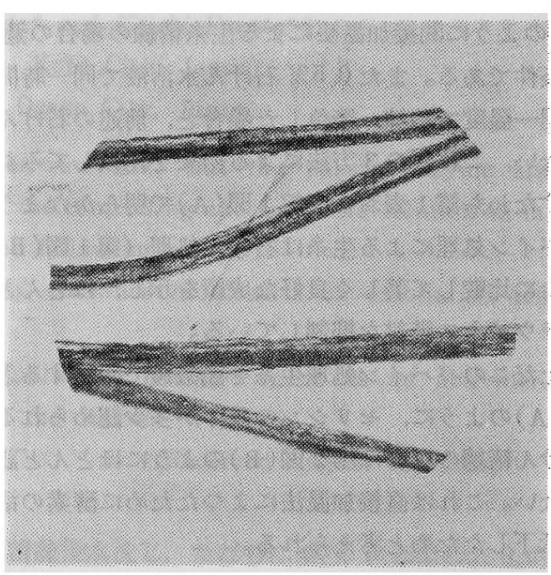

Fig. 4. Degummed silk treated with papain solution

と第 4 図で明らかなよらに多少セリシンの残存は認めら, れるので，これが原因でラウジネス織維の発生を㧕制し ているのでないかと考えられる。

（3）付活郕の種類をかえ，間接加温法によつた場合 パパイン䤃素の付活剤としてはイオウ元素を含有した ものがいので, ハイドロサルファイト，キオ硫酸ソー ダ，亜硫酸ソーダを付活剂とし，同一試料(供試生系D) について $70^{\circ} \mathrm{C} て ゙ ~ 4$ 時間精練し，染色工程は前述のよう に行ないそそのラウジネス緎維発生状態を比較した結果

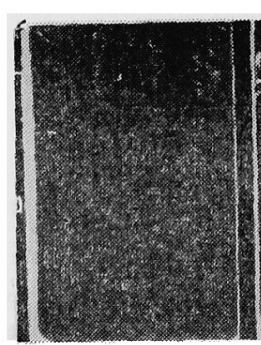

(90)

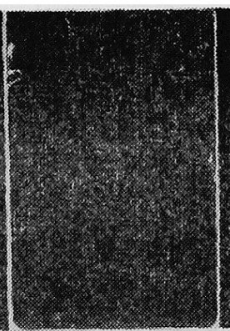

(95)

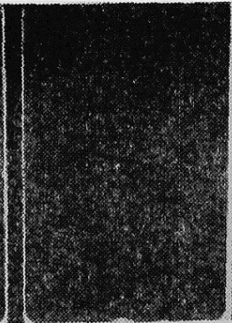

(95)

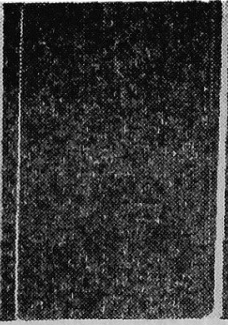

(95)

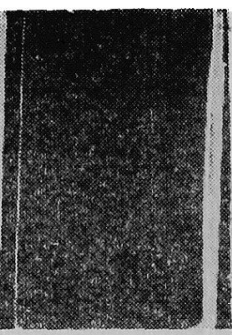

(95)

Fig. 3. Representative photograph in test No. 17. 
は次の第 3 表および第 5 図 (A), (B)，(C) のようで山 る。なおく゚パインの重量割合, 付活剂の混入割合なども すべて前回の実験と同一方法で行ない，本実験に㧍いて あ練堿率を求めてみた。

すなわちチオ硫酸ソーダを付活剤とした場合は残存七

\begin{tabular}{|c|c|c|c|c|c|}
\hline 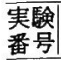 & 付活㨈の種類 & 平均点 & 劣等点 & 等級点 & 練減率 \\
\hline 19 & $\begin{array}{l}\text { ハイドロサルフ } \\
\text { フイト }\end{array}$ & 73.50 & 66.00 & 69.75 & $23.03^{\%}$ \\
\hline 20 & チオ硫酸ソーダ & 94.50 & 90.00 & 92.25 & 16.18 \\
\hline 21 & 亚硫酸ソーダ & 78.75 & 72.00 & 75.37 & 22.32 \\
\hline
\end{tabular}

リシン量も多く，適正な結果でないことは明らかであ り，亜硫酸ソーダおよびハイドロサルファイトはその混 合割合を变觉れば理想的の付活郕として使用価值がある ように見受けられる。

（4）ハイドロサルファイトの混合割合を変えた場合 前記の実験においてハイドロサルファイトが付活剤と して非常に有効のように見受けられたので同一試料（供 試生系D）を用い，精練槽の溶液量 $70 l$ とし，ハイド ロサルファイトの混合割合を第 4 表の上らに変光て，70 ${ }^{\circ} \mathrm{C}$ 前後で 4 時間精練し, 後前述と同一の染色方法で処理 した後，そのラウジネス出現状態を検討した結果は次の 第4 表拉よび第 6 図 (A), (B), (C), (D), (E) のようであ

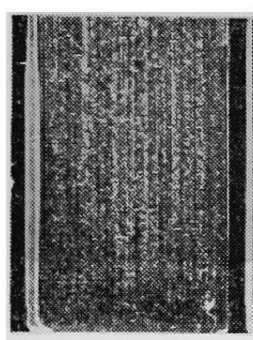

(60)

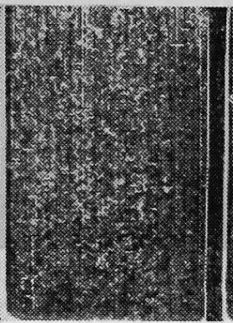

(60)

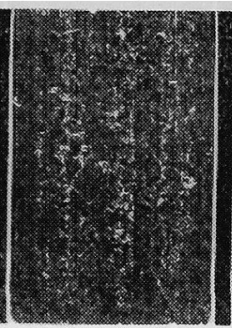

(75)

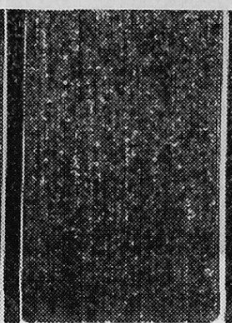

(70)

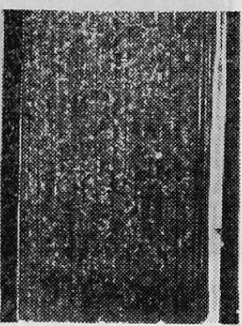

(65)

Fig. 5 (A). Representative photograph in test No. 19.

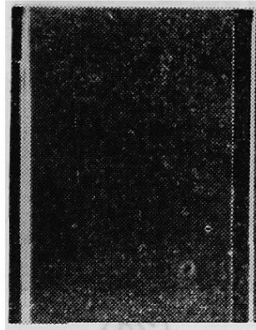

$(100)$

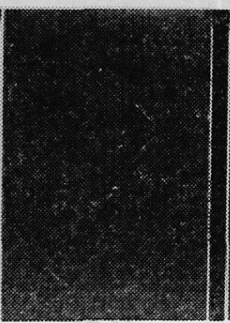

(75)

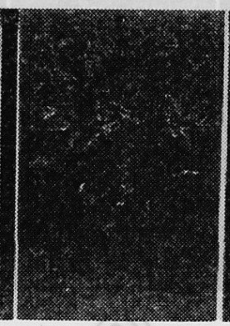

(95)

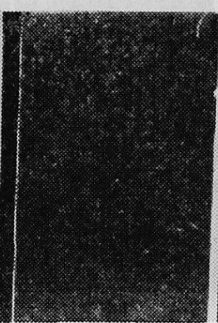

(95)

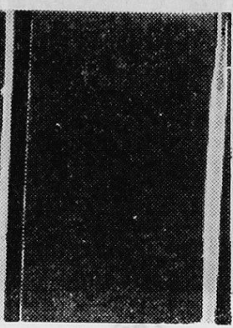

$(100)$

Fig. 5 (B). Representative photograph in test No. 20.

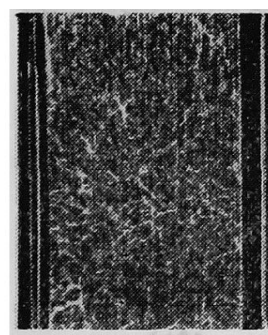

(6o)

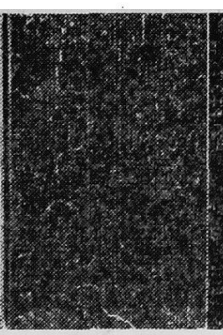

(75)

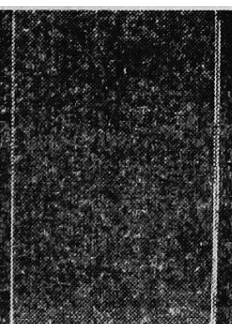

(80)

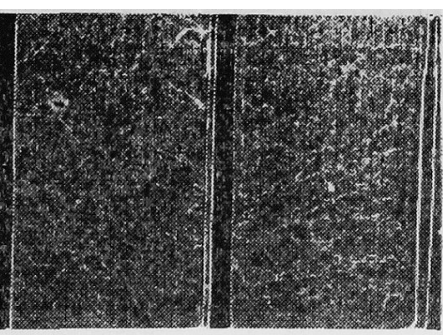

(70)
(65)

Fig. 5 (C). Representative photograph in test No. 21. 


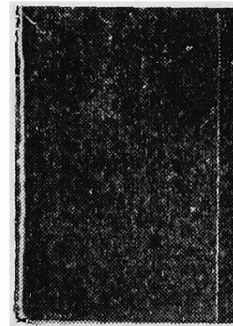

(80)

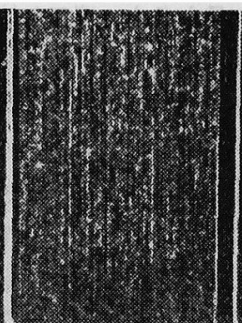

(60)

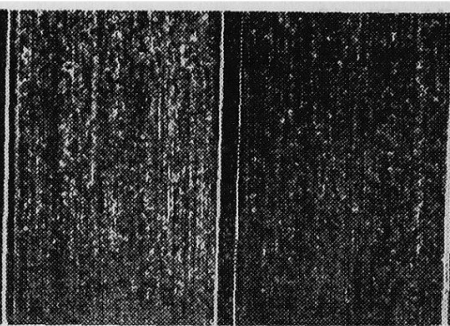

(60)

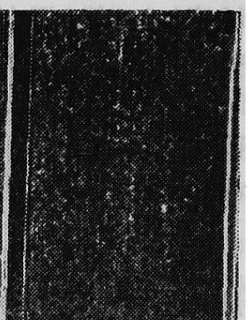

(75)

Fig.6(A). Representative photograph in test No. 22.

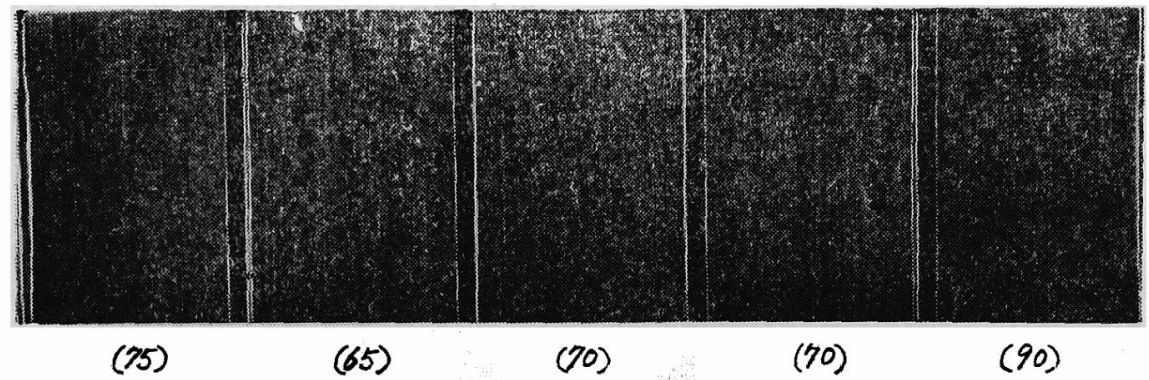

Fig.6(B). Representative photograph in test No. 23.

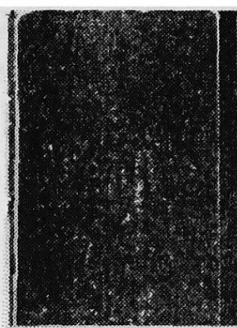

(90)

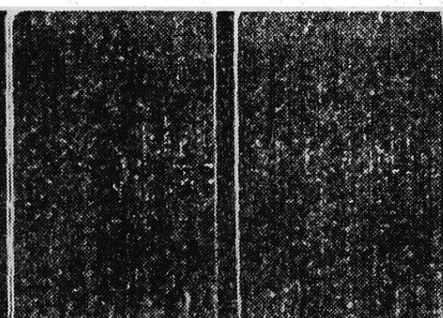

(60)

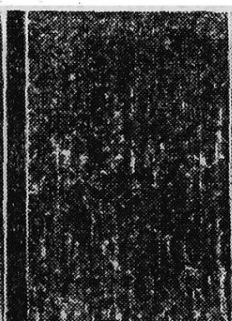

(65)

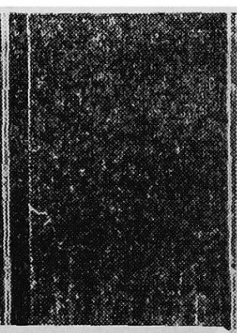

(70)

Fig.6(C). Representative photograph in test No. 24.

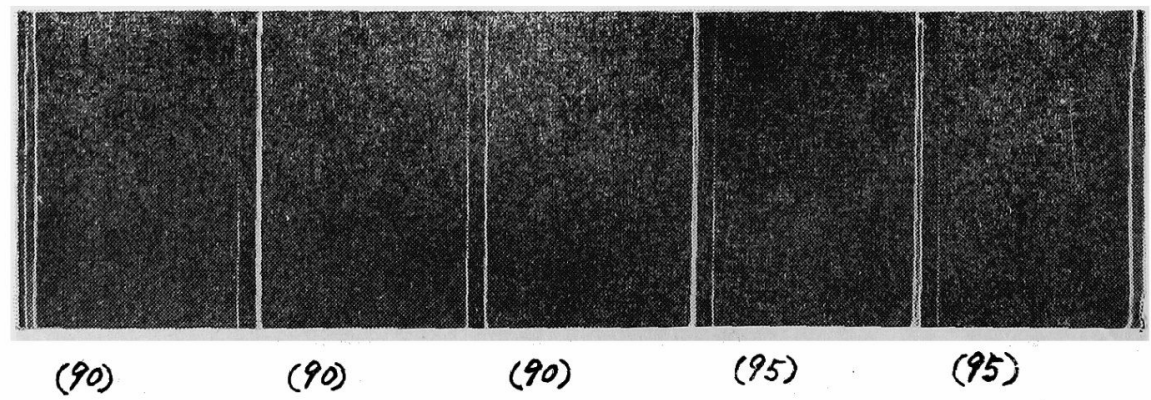

Fig.6 (D). Representative photograph in test No. 25. 


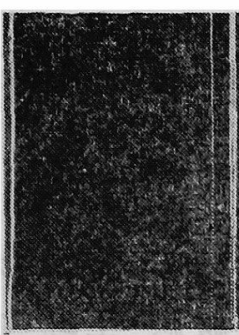

(95)

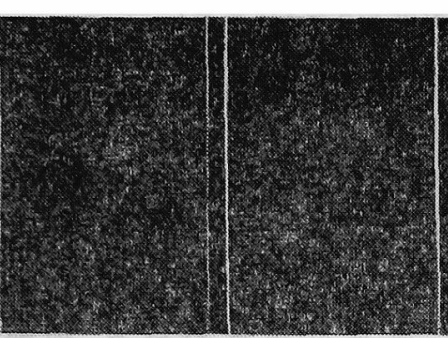

(95)

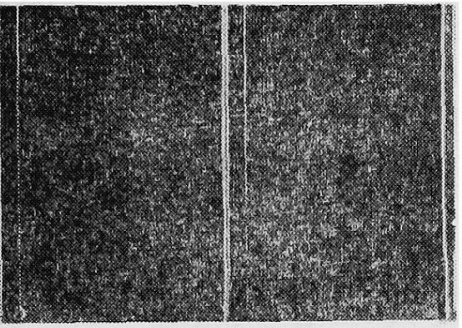

(95)

$(100)$

Fig.6(E). Representative photograph in test No. 25.

る。また本突験においても練減率を求めた。

\begin{tabular}{|c|c|c|c|c|c|c|}
\hline $\begin{array}{l}\text { 実驗 } \\
\text { 番点 }\end{array}$ & $\because \div 1$ & $\begin{array}{l}\text { ヘ1トロ } \\
\text { のプー } \\
\text { の重量 }\end{array}$ & 平均点 & 劣等点 & 等䋁点 & 䌐減率 \\
\hline 22 & $\begin{array}{r}g \\
70\end{array}$ & $100^{\mathrm{g}}$ & 67.50 & 65.00 & 66.25 & 22.79 \\
\hline 23 & 70 & 70 & 73.00 & 65.00 & 69.00 & 22. 60 \\
\hline 24 & 70 & 30 & 75.00 & 64.00 & 69.50 & 21.80 \\
\hline 25 & 70 & 10 & 92.00 & 89.00 & 90.50 & 12.90 \\
\hline 26 & 0 & 70 & 96,00 & 95.00 & 95. 50 & 1. 40 \\
\hline
\end{tabular}

第4表で明らかなようにパパインの一定量に対してハ イドロサルファイトが少なくなる程練減率は減少し, 残 存セリシン量は多くなり, 従つてラウジネス繊維もこの 残存セリシンによつて多少いんぺいされるので成績もよ くなるのは当然であるが，本試料を用い，石けんで沸滕 状態で行なつた実験番号 16 と比較しても, 実験番号 22 , 23 は良好な結果を示している。

実験番号 25 のハドロサルフォイト $10 \mathrm{~g}$ の場合と,

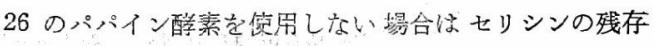
はいちじるしく、ラウジネス繊維は抑制されたかに見受 けられるが適正精練が行なうれていないので論外であ。 ๖。

\section{4. 結 論}

以上の実験結果さ要約すると次のようになる。すなわ ちパパイン酵集はラウジネス抑制のための精練剤として は非常に有効であり，從来の石けえ液によるものより等 級点で 7〜10 点位良好な結果示した。また付活剤とし ては $\mathrm{NaHSO}_{3}$ ，ハイドロサフォイト，亜硫酸ソーダな どは有効で，特にハイドミサルフフイトはパパインと等 量以下で足り，他の付活郕より良行な傾向が認められ。 た。

文献

1) 後藤泰一; 㵶工学誌, 5,4 (1939)

2) 平田, 古田; 寔系学会関西支部 24 回研究発表会 (1962) 